\title{
Numbers Total Score
}

National Cancer Institute

\section{Source}

National Cancer Institute. Numbers Total Score. NCI Thesaurus. Code C120339.

The total score from the Children's Memory Scale Numbers Forward and Numbers Backward. 